\title{
A hipertrófiás myocardium reverz elektromos remodellációjának vizsgálata patkánymodellben
}

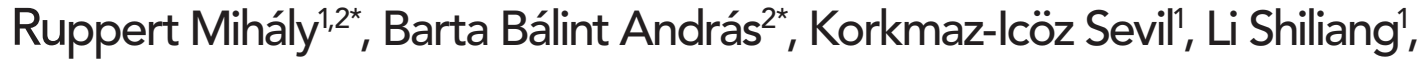 \\ Oláh Attila², Mátyás Csaba², Németh Balázs Tamás², Benke Kálmán², \\ Sayour Alex Ali², Karck Matthias', Merkely Béla², Radovits Tamás ${ }^{\star}$, Szabó Gábor ${ }^{1 *}$ \\ ${ }^{1}$ Ruprecht-Karls Egyetem Szívsebészeti Klinika, Kísérleti Kutató Laboratórium, Heidelberg \\ ${ }^{2}$ Semmelweis Egyetem, Kísérleti Kutató Laboratórium, Városmajori Szív- és Érsebészeti Klinika, Budapest \\ Levelezési cím: \\ Dr. Ruppert Mihály, SE, Városmajori Szív- és Érgyógyászati Klinika, Kardiológiai Központ - Kardiológiai Tanszék, \\ Kísérleti Kutató Laboratórium, 1122 Budapest, Városmajor u. 68., e-mail: ruppertmis@gmail.com
}

Bevezetés: Széles körben elfogadott, hogy a fokozott nyomásterhelés által előidézett bal kamrai (BK) szívizom-hipertrófia (BKH) kialakulását a myocardium fokozott aritmia hajlama kíséri. Szintén ismert, hogy a fokozott utóterhelés megszüntetése az átépült szívizomszerkezet visszaalakulását, ún. reverz remodellációját eredményezheti, amely együtt járhat az aritmogenitás egyidejü csökkenésével. Ennek ellenére a myocardium reverz elektromos átépülését kísérő sejtszintű változásokat kevesen vizsgálták. Ezért jelen tanulmányunkban célunk volt a BKH kialakulásának és visszafejlődésének elektrokardiográfiás nyomonkövetése, és az elektrofiziológiai változások hátterében meghúzódó sejtszintű és funkcionális történések azonosítása.

Módszerek: Patkánymodellünkben a fokozott nyomásterhelést az aorta mütéti beszúkítésével (aortic banding; $A B$ ) biztosítottuk 6 (AB-6hét), illetve 12 hét (AB-12hét) időtartamra. A szívizom-hipertrófia kialakulása után, a reverz remodellációt a szűkület eltávolításával (Debanding) idéztük elö. A kontrollcsoportot áloperált állatok alkották. A BKH kialakulását, és visszafejlődését elektrokardiográfiával és szívultrahang-vizsgálattal követtük. A fehérje-expressziót western blottal tanulmányoztuk. A miokardiális fibrózist picrosirius vörös festéssel vizsgáltuk.

Eredmények: A szűkület eltávolítása a $B K H$ jelentős visszafejlődését eredményezte, amelynek mértéke korrelált a megnyúlt korrigált QT-intervallum regressziójával. (cQT: $68,7 \pm 1,6$ vs. 91,0 $\pm 1,9$ ms Debanded vs. AB-12hét, $p<0,05$ ). A fokozott nyomásterhelés megszüntetése továbbá eredményesen előzte meg a bal kamra funkcionális hanyatlását, és egyúttal megőrizte a pitvar-kamrai átvezetést (PQ: 47,5 $\pm 1,2$ vs. $53,8 \pm 1,9$ ms Debanded vs. $A B-12$ hét, $p<0,05)$. Mindemellett az utóterhelés csökkentése megakadályozta a QRS-komplexum kiszélesedését (QRS: $21,8 \pm 0,5$ vs. $24,9 \pm 0,7$ ms Debanded vs. AB-12hét, $p<0,05$ ), amellyel az intersticiális kollagén mennyiségének csökkenése állt párhuzamban.

Következtetések: A BKH visszafejlődése a szívfunkció romlásának és a miokardiális fibrózis súlyosbodásának gátlásával együtt hozzájárul a nyomáscsökkenés által kiváltott reverz elektromos remodellációhoz.

Kulcsszavak: bal kamrai szívizom-hipertrófia, fokozott nyomásterhelés, nyomásterhelés csökkentése, elektrokardiogram, reverz elektromos remodelláció

Reverse electrical remodeling following pressure unloading in a rat model of myocardial hypertrophy

Introduction: Pressure overload-induced left ventricular myocardial hypertrophy (LVH) is characterized by increased proarrhythmic vulnerability. In contrast, pressure unloading leads to reverse remodeling and decreases LVH-associated arrhythmogenicity. However, cellular changes that occur during reverse electrical remodeling have been studied less. Therefore, we aimed to provide an electrocardiographic characterization of a rat model of LVH that underwent pressure unloading and to simultaneously identify the underlying cellular and functional alterations.

Methods: LVH was induced in rats by abdominal aortic banding for 6 or 12 weeks. Sham-operated animals served as controls. Pressure unloading was evoked by removing the aortic constriction after week 6 (Debanded). Serial echocardiography and electrocardiography were performed to investigate the development and the regression of LVH. Protein expression levels were detected by western blot. Myocardial fibrosis was assessed by Picrosirius red staining.

Results: Pressure unloading resulted in the regression of LVH in correlation with the reversion of the prolonged corrected QT interval (cQT: $68.7 \pm 1.6$ vs. 91.0 \pm 1.9 ms Debanded vs. AB week 12, $P<0.05$ ). Furthermore, pressure unloading prevented the functional decompensation of $\mathrm{LVH}$ and simultaneously preserved adequate atrioventricular conduction (PQ: $47.5 \pm 1.2$ vs. $53.8 \pm 1.9$ ms Debanded vs. AB week $12, P<0.05)$. Finally, pressure unloading effectively preceded the broadening of the $Q R S$ complex (QRS: $21.8 \pm 0.5$ vs. $24.9 \pm 0.7$ ms Debanded vs. $A B$ week $12, P<0.05$ ) in parallel with the attenuation of interstitial collagen accumulation.

Conclusions: The regression of LVH with maintained cardiac function and decreased myocardial fibrosis contributes to pressure unloading-induced reverse electrical remodeling.

Keywords: left ventricular hypertrophy; aortic banding; pressure unloading; reverse electrical remodeling

*A szerzők azonos mértékben járultak hozzá a közleményhez

Készült Ruppert et al. Hypertens Res 2017; 40: 637-645. közleményének felhasználásával a SpringerNature Kiadó írásos engedélyével (1) 


\section{Bevezetés}

A bal kamra hosszan tartó nyomásterhelésének (pl. hipertónia, aortastenosis) hatására bal kamrai szívizom-hipertrófia fejlődik ki (BKH), amely a malignus kamrai aritmiák és így a hirtelen szívhalál alapvető rizikófaktora (2). Ennek magyarázatául szolgál, hogy a krónikusan fennálló hemodinamikai terhelés nemcsak a szívizomsejtek méretének növekedésével, hanem jellegzetes elektrofiziológiai változásokkal is együtt jár. Erre utal az elektromos remodelláció fogalma, amely fokozott intersticiális fibrózist (3), a $\mathrm{Ca}^{2+}$ homeosztázis fehérjéinek megváltozott expresszióját (4) valamint a réskapcsolatok lecsökkent számát foglalja magába (5). Ezen celluláris változások a BKH kialakulása során eltérő időben jelentkeznek, és eltérő mechanizmussal vezetnek kamrai aritmiákhoz.

A BKH-t kísérő leggyakoribb elektrofiziológiai eltérés az akciós potenciál (AP) megnyúlása, amely az EKG-n megnyúlt QT-intervallum formájában jelenik meg. Hátterében repolarizációs zavar áll (3), amely a csökkent kifelé irányuló $\mathrm{K}^{+}(6)$, illetve a fokozott befelé irányuló $\mathrm{Ca}^{2+}$-áramra (4) vezethető vissza. A repolarizációs idő megnyúlása a korai és a késői utódepolarizációkra egyaránt hajlamosít $(7,8)$. Ezzel összhangban a korán, funkcionális szempontból még kompenzált stádiumban lévő BKH mellett fellépő hirtelen szívhalál esetekért elsősorban triggerelt aktivitások felelnek (3).

Továbbá a vezetés lassulására utaló QRS-komplexum kiszélesedése szintén gyakran megfigyelhető dekompenzált BKH-ban és szívelégtelenségben (9), amit a jelentős miokardiális fibrózis (10), és a réskapcsolatok alacsony száma magyarázhat (5). A vezetés sebessége viszont nem egyenlő mértékben lassul minden szívizomterületen, ezért a myocardium refrakteritás szempontjából inhomogénné válik (11), amely folyamatok együttesen re-entry típusú kamrai tachyarrhythmiák kialakulására hajlamosítanak.

Továbbá a BKH-t és szívelégtelenséget kísérő elektrofiziológiai változások a pitvarokban is manifesztálódnak. Ezt támasztja alá, hogy szívelégtelen nyulakban szignifikánsan hosszabb PR-intervallumot, a pitvar-kamrai junkció megnyúlását és bizonyos ioncsatorna expreszsziós eltéréseket találtak (12).

A fokozott nyomásterhelés megszüntetése ugyanakkor, megfelelően korai stádiumban, az átépült szívizomszerkezet visszaalakulását, ún. reverz remodellációját eredményezheti $(13,14)$, amely előnyös elektrofiziológiai változásokkal is együtt járhat. Utóbbit támasztották alá Rials és munkatársai (15), akik aorta szükített majd a szükületet eltávolított macskamodellben a $\mathrm{BKH}$ regresszióját követően normalizálódott monofázisos AP hosszról (APH), szignifikánsan magasabb fibrillációs küszöbről és kevesebb kiváltható polimorf kamrai aritmiáról számoltak be. Mindezek ellenére jelenleg nem áll rendelkezésre adat a reverz elektromos remodelláció mechanizmusairól.

Ezért patkánykísérletünkben célunk volt (1) a BKH kiala- kulásának és visszafejlődésének elektrokardiográfiával történő karakterizációja, valamint (2) a reverz elektromos remodelláció háttérében meghúzódó sejtszintủ és funkcionális elváltozások egyidejü azonosítása.

\section{Módszerek}

\section{Állatok}

Hím Sprague-Dawley patkányokat (n=51) (160-180 g; Charles River, Sulzfeld, Németország) szabványos laboratóriumi körülmények között tartottunk. Vizsgálatainkat a kísérleti állatok tartásáról és felhasználásáról szóló nemzetközi szabályoknak (Guide for the Care and Use of Laboratory Animals, US National Institues of Health 1996; 85-23) megfelelően végeztük, az etikai bizottság engedélyével.

\section{A hasi aorta beszúkítésére és a szúkület eltávolítására alkalmazott eljárások}

A bal kamra fokozott nyomásterhelését a hasi aorta mütéti beszűkítésével idéztük elő (aortic banding, $A B$ ) $(n=33)$, ahogy azt már korábban ismertettük $(16,17)$. Röviden összefoglalva, medián laparotomiát követően egy 2-0-s sebészi fonál felhasználásával az aorta abdominális szakaszát, a suprarenalis síkban egy 22 G-s tű külső átmérőjével megegyező szélességüre szűkítettük (18). Az áloperált (Sham) állatok $(n=18)$ azonos eljáráson mentek keresztül, az aorta beszűkítésétől eltekintve. A 6. hét elteltével az aortaszúkített állatok egy részénél $(n=11)$ a fonál eltávolításra került (Debanded), a fokozott nyomásterhelés megszüntetése céljából. A posztoperatív fájdalomcsillapítást szubkután adott buprenorfin injekcióval biztosítottuk.

\section{Kísérleti csoportok}

6 héttel az első mütétet követően állatainkat az alábbi öt csoportba osztottuk:

1. 6 hetes aortaszúkített csoport (AB-6hét; $n=8)$, a csoport tagjait aortaszűkítést követően 6 hétig követtük;

2. 6 hetes áloperált csoport (Sham-6 hét; $n=8$ ), a csoport tagjait, áloperációt követően 6 hétig követtük;

3. 12 hetes aortaszúkített csoport (AB-12hét; n=14), a csoport tagjait aortaszükítést követően 12 hétig követtük:

4. 12 hetes áloperált csoport (Sham-12 hét; $n=10$ ), a csoport tagjait, áloperációt követően 12 hétig követtük;

5. 12 hetes aortaszükületet eltávolított csoport (Debanded; n=11), a csoport tagjai aortaszükítésen mentek keresztül, majd a 6 . hét után a szükület eltávolításra került és az állatokat a 12. hét végéig követtük.

A szívek elektromos, morfológiai és hemodinamikai változásait a 3., 6., 9., és 12. héten végzett elektrokardiográfiás és echokardiográfiás mérésekkel követtük nyomon. A kísérleti periódus végén invazív vérnyomásmérést hajtottunk végre, majd meghatároztuk a szív(HW) és tüdő (LW) tömegeket és a tibia hosszát (TL). 


\section{Echokardiográfia}

A vizsgálatokat a korábbiakban ismertetettek szerint hajtottuk végre (19). Röviden: az állatokat 100\%-os oxigénnel történő lélegeztetés mellett $5 \%$-os indukciós, majd 1,5-2\%-os fenntartó izoflurán anesztéziának vetettük alá, miközben testhőmérsékletüket automata fütőpad segítségével $37^{\circ} \mathrm{C}$-on tartottuk. Egy HDI 5000 CV UH-géphez (ATL Ultrasound, Philips, Bothell, WA, USA) kapcsolt $10 \mathrm{MHz}$-es lineáris fejjel két dimenziós parasternalis hosszú és rövid, valamint a papilláris izmot középen metsző M-módú felvételeket készítettünk, majd ezeket szoftveres kiértékelésnek vetettük alá (HDI Lab, Philips, Bothell, WA, USA).

A következő paramétereket határoztuk meg: BK elülső falvastagság (AWT), BK hátulsó falvastagság (PWT) diasztoléban (d) és szisztoléban (s), valamint BK végdiasztolés- (LVEDD) és végszisztolés (LVESV belső átmérő. Minden mérést háromszor hajtottunk végre, eredményeiket átlagoltuk.

A BK-i szívizomtömeget (LV mass) a módosított Devereux-módszer (20) alapján számítottuk: LVmass $(g)=\{[(\mathrm{L}-$ VEDD+AWTd+PWTd)]3-LVEDD3) × 1,04\} × 0,8+0,14 $A$ végdiasztolés (LVEDV) és végszisztolés (LVESV) térfogatokat a prolate modell szerint határoztuk meg: LVEDV $=[(3,14 / 6) \times$ LVEDD2] $\times L$ (21). A frakcionális rövidülést (FS) és az ejekciós frakciót (EF) a következő képletek alapján számítottuk: FS=[(LVEDD-LVESD)/ LVEDD] × 100 és EF=(LVEDV-LVESV/LVEDV $) \times 100$.

\section{Elektrokardiográfia}

Szubkután elhelyezett tủelektródákkal 12 elvezetéses EKG-t regisztráltunk (Mortara Instrument, Milwaukee, WI, USA) (19). Az érzékenységet $10 \mathrm{~mm} / \mathrm{mV}$-ra, a futási sebességet $50 \mathrm{~mm} / \mathrm{s}$-ra állítottuk. A kiértékelést a II-es elvezetés alapján végeztük, amely során a következő paraméterek kerültek meghatározásra: szívfrekvencia; PQ- és QT-intervallumok, illetve QRS-komplexum hossza. QT-intervallumot a QRS első kitérésétől a T-hullám végéig mértük, és a korrekcióját $\left(Q T_{c}\right)$ a Bazett-formula patkányokhoz igazított változatával számoltuk: $\left[n Q T_{c}=Q T /(R R / f) 1 / 2\right](22)$.

\section{Invazív hemodinamikai vizsgálat}

A kísérleti periódus végén invazív hemodinamikai vizsgálatot hajtottunk végre (16) pentobarbitállal $(60 \mathrm{mg} /$ $\mathrm{kg}$, ip.) altatott, tracheotomizált és intubált patkányokon, amelyek testhőmérsékletét fütőpad segítségével végig $37{ }^{\circ} \mathrm{C}$-on tartottuk. A bal véna jugularis externát folyadék adagolás céljából polietilén katéterrel kanüláltuk, míg a jobb arteria carotis communison egy $2 \mathrm{~F}-\mathrm{s}$ nyomás- és térfogatmérő konduktancia mikrokatétert (SPR-838, Millar Instruments, Houston, Tx, USA) vezettünk az aorta ascendensbe, majd a stabilizációs idő leteltével a bal kamrába. A következő paramétereket határoztuk meg: szisztolés és diasztolés vérnyomás (sBP és dBP), artériás középnyomás (MAP) és BK-i végszisztolés (LVESP) és végdiasztolés (LVEDP) nyo- másértékek. A hemodinamikai mérések végeztével az állatokat kivéreztetéssel eutanizáltuk.

\section{Szövettan}

A BK-i myocardium darabjait 4\%-os paraformaldehid oldatban fixáltuk és paraffinba ágyaztuk. A hipertrófia értékelése céljából a BK 5 um-es, transmuralis, azonos magasságból származó, hematoxillin-eozinnal festett metszetein lemértük és átlagoltuk 100 db longitudinálisan orientált cardiomyocyta transnuclearis átmérőjét (CD). A miokardiális fibrózis mértékét picrosirius vörössel festett metszeteken szemikvantitatív pontozás segítségével osztályoztuk (0: nincs jelen, 1: enyhe, 2: közepes és 3 : súlyos) állatonként 20 véletlenszerüen kiválasztott látótérben.

\section{Immunoblot analízis}

Western blotot végeztünk a korábban ismertetett módon (23). BK-i szívizomszövetet homogenizáltunk, majd a fehérje oldatokat gélelektroforézisnek vetettük alá. $A$ fehérjéket nitrocellulóz membránra blottoltuk és elsődleges antitestekkel inkubáltuk. A vizsgált célpontjaink a következők voltak: Connexin-43 (Cx43) L-típusú $\mathrm{Ca}^{2+}$-csatorna Protein a1C (LTCC) és szarkoplazmás/endoplazmás retikulum $\mathrm{Ca}^{2+}$-ATPáz 2 (SERCA2). A membránokat tormaperoxidázzal konjugált másodlagos antitesttel inkubáltuk. Az immunblotokat kemilumineszcens módszerrel (PerkinElmer, Rodgau-Juegesheim; Németország) hívtuk elő és az intenzitásokat a Chemi-smartTM 5100 rendszerrel (Peqlab, Biotechnologie, GmbH, Erlangen, Németország) detektáltuk. A fehérje denzitásokat kvantifikáltuk, a denzitás értékeket GADPH-ra normalizáltuk és tüntettük fel.

\section{Statisztika}

Minden adatot átlagérték $\pm S E M$ formájában adtunk meg. Az adatok normáleloszlását Shapiro-Wilk-teszttel ellenőriztük. Normáleloszlás esetén, egy utas varianciaanalízist (ANOVA) és Tukey-féle post hoc tesztet hajtottunk végre. Normáleloszlás hiányában KruskalWallis és Dunn-tesztet végeztünk. A sorozatos EKGés UH-vizsgálatok eredményeit csoporton belül ismétléses egy utas ANOVA-val és Tukey-féle post hoc teszttel vizsgáltuk. A különböző paraméterek közti korrelációkat Spearman-teszttel igazoltuk. $A p<0,05$ értékeket tekintettük statisztikailag szignifikánsnak.

\section{Eredmények}

Az aorta szưkítésének és a szúkület eltávolításának hatása az artériás vérnyomásra $\mathrm{Az}$ aorta abdominalis mútéti beszükítése szignifikánsan emelkedett BPs-t, BPd-t és MAP-t eredményezett az AB-6hét és $A B-12$ hét csoportokban, míg a szükület eltávolítása az említett paraméterek csökkenését idézte elő a Debanded állatoknál (1. táblázat). 
1. TÁBLÁZAT. A vizsgálati csoportok alapparaméterei

\begin{tabular}{|c|c|c|c|c|c|}
\hline & Sham 6. hét & Sham 12. hét & AB 6. hét & $A B$ 12. hét & Debanded 12. hét \\
\hline HW (g) & $1,25 \pm 0,02$ & $1,54 \pm 0,05$ & $2,08 \pm 0,10^{*}$ & $2,49 \pm 0,07^{\text {*\# }}$ & $1,70 \pm 0,08^{\# \$}$ \\
\hline HW/TL (g/cm) & $0,31 \pm 0,01$ & $0,35 \pm 0,01$ & $0,50 \pm 0,02^{*}$ & $0,57 \pm 0,02^{* \#}$ & $0,38 \pm 0,02^{\# \$}$ \\
\hline LW (g) & $1,49 \pm 0,06$ & $1,83 \pm 0,03$ & $1,82 \pm 0,06$ & $2,12 \pm 0,19$ & $1,90 \pm 0,05$ \\
\hline $\mathrm{LW} / \mathrm{TL}(\mathrm{g} / \mathrm{cm})$ & $0,37 \pm 0,02$ & $0,41 \pm 0,01$ & $0,44 \pm 0,01$ & $0,48 \pm 0,04$ & $0,43 \pm 0,01$ \\
\hline SBP (Hgmm) & $144 \pm 3$ & $143 \pm 5$ & $224 \pm 8^{*}$ & $201 \pm 9^{*}$ & $173 \pm 5^{\star \# \$}$ \\
\hline DBP (Hgmm) & $117 \pm 2$ & $118 \pm 3$ & $158 \pm 4^{*}$ & $153 \pm 5^{*}$ & $135 \pm 3^{\star \# \$}$ \\
\hline MAP (Hgmm) & $126 \pm 2$ & $126 \pm 3$ & $180 \pm 4^{*}$ & $171 \pm 6^{*}$ & $148 \pm 3^{* \# \$}$ \\
\hline LVESP (Hgmm) & $133,4 \pm 5,9$ & $121,0 \pm 7,4$ & $195,8 \pm 8,5^{*}$ & $184,0 \pm 7,7^{*}$ & $166,0 \pm 3,8^{* \#}$ \\
\hline LVEDP (Hgmm) & $4,5 \pm 0,6$ & $5,5 \pm 0,6$ & $5,8 \pm 1,0$ & $8,2 \pm 1,4$ & $5,6 \pm 0,4$ \\
\hline
\end{tabular}

Rövidítések: AB, aorta szűkített; DBP, diasztolés vérnyomás; HW/TL szívtömeg/tibiahossz; LVEDP, bal kamrai végdiasztolés nyomás; LVESP, bal kamrai végszisztolés nyomás; LW/TL, tüdőtömeg/tibiahossz; MAP, artériás középnyomás; SBP, szisztolés középnyomás. Minden adatot átlagérték $\pm S E M$ formájában adtunk meg. ${ }^{*} p<0,05$ vs. azonos korú Sham, ${ }^{\#} p<0,05$ vs. AB-6hét, ${ }^{\$} p<0,05$ vs. AB-12hét.

\section{Miokardiális remodelláció és a nyomásterhelés megszüntetése által indukált reverz remodelláció}

Az AB-csoportokban a BKH fennállását az ultrahanggal mért BK-i tömegindexek már a 3 . hét leteltével igazolták (2. táblázat). Ezt a 6 . héten megfigyelt $C D$ és
HW/TL arányok is alátámasztották (1. táblázat; $1 . A, B$ és $3 B$ ábrák). Ellenben a picrosirius-festett metszeteken nem találtunk különbséget a miokardiális fibrózist illetően a 6 hetes aortaszükített csoportban (1. A és $C$ ábrák). A 6. hét után a szívizom-hipertrófiára funkcionális szempontból kompenzált stádium volt jellemző,

2. TÁBLÁZAT. Szívultrahang-paraméterek változásai a szívizom-hipertrófia kialakulása és visszafejlődése során

\begin{tabular}{|c|c|c|c|c|}
\hline & & Sham $(n=10)$ & $A B(n=14)$ & Debanded $(n=11)$ \\
\hline \multirow[t]{6}{*}{ 3. hét } & Testtömeg (g) & $370 \pm 8$ & $354 \pm 5$ & $350 \pm 11$ \\
\hline & LV mass index (g/kg) & $2,6 \pm 0,1$ & $4,5 \pm 0,2^{*}$ & $4,9 \pm 0,2^{*}$ \\
\hline & LVEDV $(\mu \mathrm{l})$ & $441,8 \pm 19,8$ & $412,2 \pm 16,0$ & $471,6 \pm 20,9$ \\
\hline & LVESV $(\mu \mathrm{l})$ & $133,3 \pm 9,7$ & $113,5 \pm 7,3$ & $138,1 \pm 11,2$ \\
\hline & FS $(\%)$ & $39,4 \pm 1,3$ & $43,8 \pm 1,3$ & $42,1 \pm 1,3$ \\
\hline & HR (ütés/min) & $341 \pm 13$ & $357 \pm 7$ & $358 \pm 9$ \\
\hline \multirow[t]{5}{*}{ 6. hét } & Testtömeg (g) & $467 \pm 7 \dagger$ & $450 \pm 11^{\dagger}$ & $471 \pm 17^{\dagger}$ \\
\hline & LV mass index $(\mathrm{g} / \mathrm{kg})$ & $2,8 \pm 0,1$ & $4,7 \pm 0,1^{*}$ & $4,4 \pm 0,2^{*}$ \\
\hline & LVEDV $(\mu \mathrm{l})$ & $605,6 \pm 24,5^{\dagger}$ & $628,5 \pm 19,8^{\dagger}$ & $625,3 \pm 28,4^{\dagger}$ \\
\hline & LVESV $(\mu \mathrm{l})$ & $198,6 \pm 7,3^{\dagger}$ & $223,2 \pm 21,5^{\dagger}$ & $201,3 \pm 13,4^{\dagger}$ \\
\hline & FS (\%) & $38,7 \pm 1,3$ & $38,0 \pm 1,8$ & $39,8 \pm 1,2$ \\
\hline Debanding & HR (ütés/min) & $337 \pm 10$ & $363 \pm 12$ & $355 \pm 13$ \\
\hline \multirow[t]{6}{*}{ 9. hét } & Testtömeg (g) & $527 \pm 9^{\dagger \ddagger}$ & $518 \pm 14^{\dagger \ddagger}$ & $482 \pm 14^{\dagger}$ \\
\hline & LV mass index (g/kg) & $2,5 \pm 0,1^{\ddagger}$ & $4,6 \pm 0,2^{*}$ & $3,3 \pm 0,2^{\# \ddagger \ddagger}$ \\
\hline & LVEDV $(\mu \mathrm{l})$ & $618,7 \pm 14,6^{\dagger}$ & $708,3 \pm 36,6^{\dagger \ddagger}$ & $619,8 \pm 29,5^{\dagger}$ \\
\hline & LVESV $(\mu \mathrm{l})$ & $197,8 \pm 11,4^{\dagger}$ & $350,1 \pm 34,1^{* \dagger \neq}$ & $210,6 \pm 14,1^{\# \dagger}$ \\
\hline & FS $(\%)$ & $40,3 \pm 1,4$ & $28,2 \pm 1,6^{\star+\ddagger}$ & $38,6 \pm 1,1^{\# \dagger}$ \\
\hline & HR (ütés/min) & $339 \pm 15$ & $353 \pm 8$ & $331 \pm 9$ \\
\hline \multirow[t]{6}{*}{ 12. hét } & Testtömeg (g) & $569 \pm 10^{\dagger \ddagger \S}$ & $556 \pm 13^{\dagger \ddagger \S}$ & $542 \pm 17^{\dagger \ddagger \S}$ \\
\hline & LV mass index (g/kg) & $2,5 \pm 0,1$ & $4,2 \pm 0,2^{* \ddagger \S}$ & $2,9 \pm 0,1^{\#+ \pm \S}$ \\
\hline & LVEDV $(\mu \mathrm{l})$ & $653,0 \pm 18,1^{\dagger}$ & $759,6 \pm 38,9^{\dagger \ddagger}$ & $657,1 \pm 26,1^{1 \ddagger}$ \\
\hline & LVESV $(\mu \mathrm{l})$ & $207,96 \pm 12,2^{\dagger}$ & $404,6 \pm 40,2^{*+ \pm}$ & $208,2 \pm 16,1^{\# \dagger}$ \\
\hline & FS $(\%)$ & $39,6 \pm 1,3$ & $25,3 \pm 1,7^{\star \star \ddagger \ddagger}$ & $39,9 \pm 1,3^{\#}$ \\
\hline & HR (ütés/min) & $328 \pm 14$ & $366 \pm 9$ & $363 \pm 11$ \\
\hline
\end{tabular}

Rövidítések: FS, frakcionális rövidülés; HR, szívfrekvencia; LVEDV, bal kamrai végdiasztolés volumen; LVESV, bal kamrai végszisztolés volumen; LV mass index, bal kamrai tömegindex. Minden adatot átlagérték \pm SEM formájában adtunk meg. ${ }^{*} p<0,05$ vs. Sham, ${ }^{\#} p<0,05$ vs. AB, ${ }^{\dagger} p<0,05$ vs. 3 hetes, ${ }^{\ddagger} p<0,05$ vs. 6 hetes, ${ }^{\S} p<0,05$ vs. 9 hetes. 

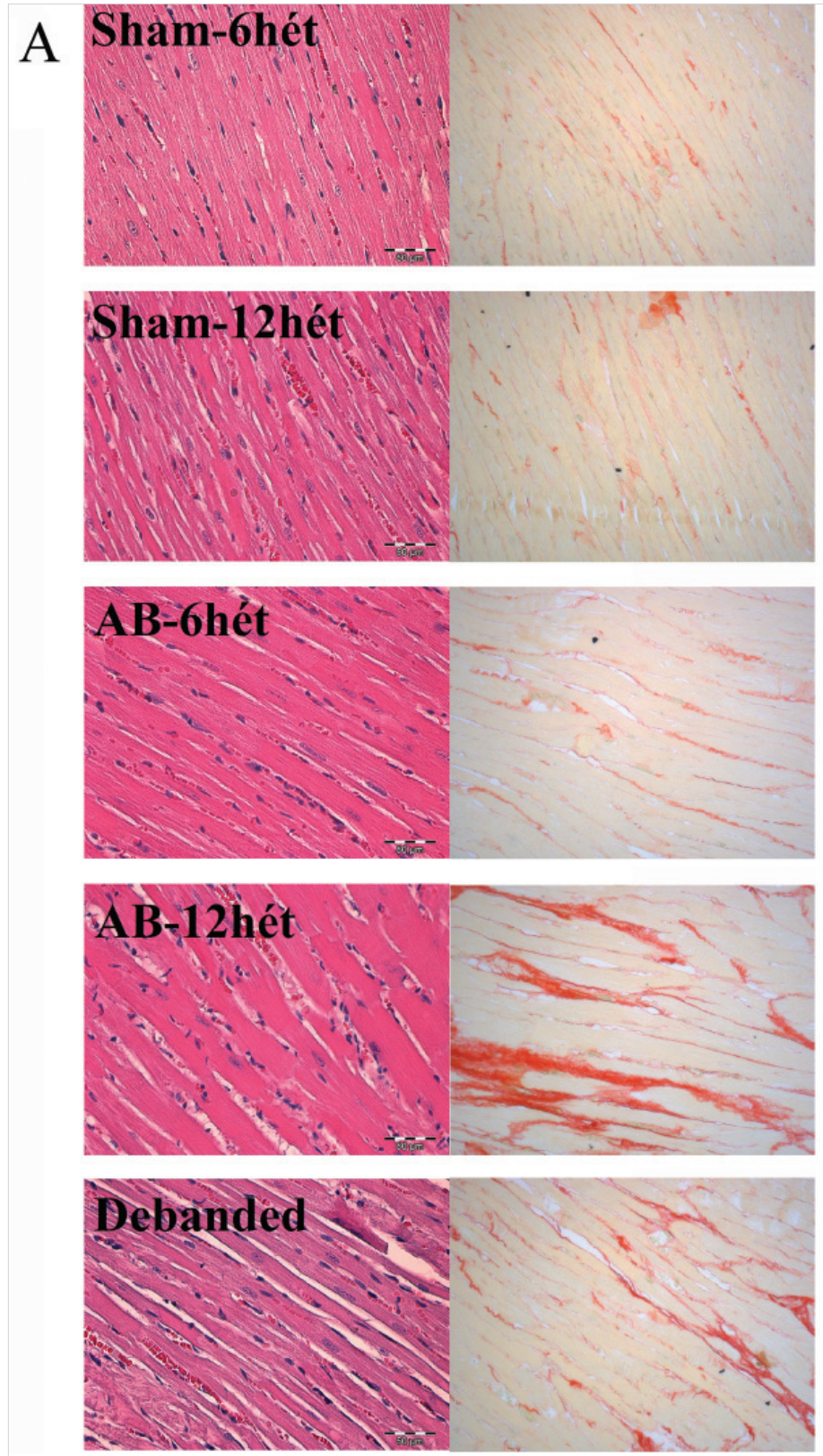

\section{B}

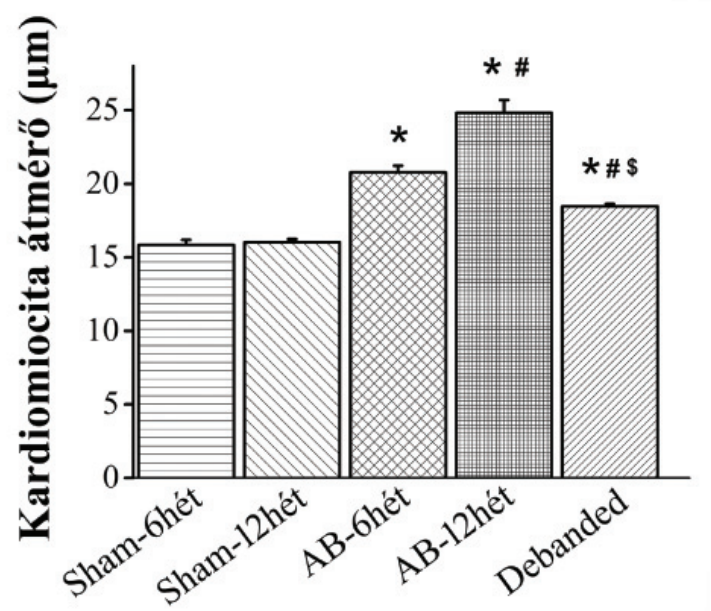

$\mathrm{C}$

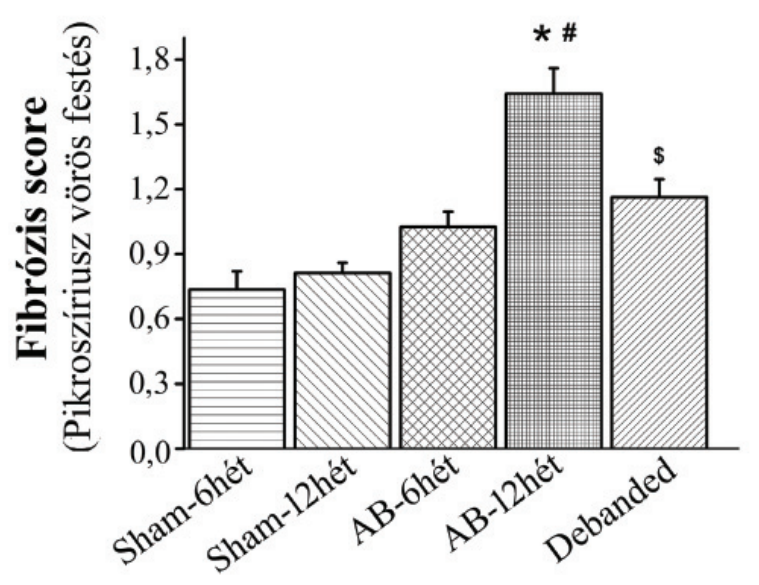

1. ÁBRA. Miokardiális remodelláció és nyomásterhelés megszüntetése által indukált reverz remodelláció. $A 6$ és 12 hetes aortaszűkített csoportjainkban a BKH fennálását a cardiomyocyta átmérő (CD) emelkedett értéke jelezte (A, $B)$, amely szignifikáns mértékben csökkent nyomásterhelés megszüntetését követően ( $A$, B). Továbbá a 12 hetes aortaszűkített csoportban jelentős mértékū miokardiális fibrózissal volt kimutatható. A nyomásterhelés megszüntetése ugyanakkor eredményesen csökkentette a kollagén instersticiális felhalmozódását is (A, C). A reprezentatív képek (a) hematoxillin-eozin- és picrosirius-festett metszetekről készültek 20-szoros nagyítással. A jelzőskála 50 um-es. Minden adatot átlagérték \pm SEM formájában adtunk meg. *p<0,05 azonos korú Sham, ${ }^{\#} p<0,05$ vs. $A B-6$ hét, ${ }^{\$} p<0,05$ vs. $A B-12$ hét

amelyet a megtartott EF- és FS-értékek igazoltak (2. táblázat, 1. A és 1. C ábrák).

A szívfunkció romlása a 9. héten kezdődött, és ez a 12. hétre további romlást mutatott. $A$ kísérleti periódus végéhez közelítve az AB-12hét csoportban az EF és a FS szignifikáns csökkenését, valamint LVESV jelentős növekedését mutattuk ki az AB-6hét csoporthoz viszonyítva (2. táblázat és 3. D ábra). Emellett a 12 hetes aortaszúkített csoportban az LVmass, CD, HW/TL arány és a miokardiális fibrózis szignifikáns emelkedé- sét észleltük, akár a kontrollcsoport akár az AB-6hét csoport értékeihez hasonlítva (1. táblázat, 1. A-C ábrák). Továbbá a LVEDP és a LW/TL arány értékeiben egy erős növekvő tendencia volt megfigyelhető az $A B$ 12 hét csoportban. A nyomásterhelés megszüntetése a Debanded csoportban az AB-12hét csoporthoz képest szignifikáns mértékben csökkentette az LVmass, CD, HW/TL arány értékeit (1. táblázat; 1.A, $B$ és 3. $B$ ábrák) és védett az intersticiális kollagén felhalmozódással szemben is (1. A és $C$ ábrák). A szükület eltávolítása 

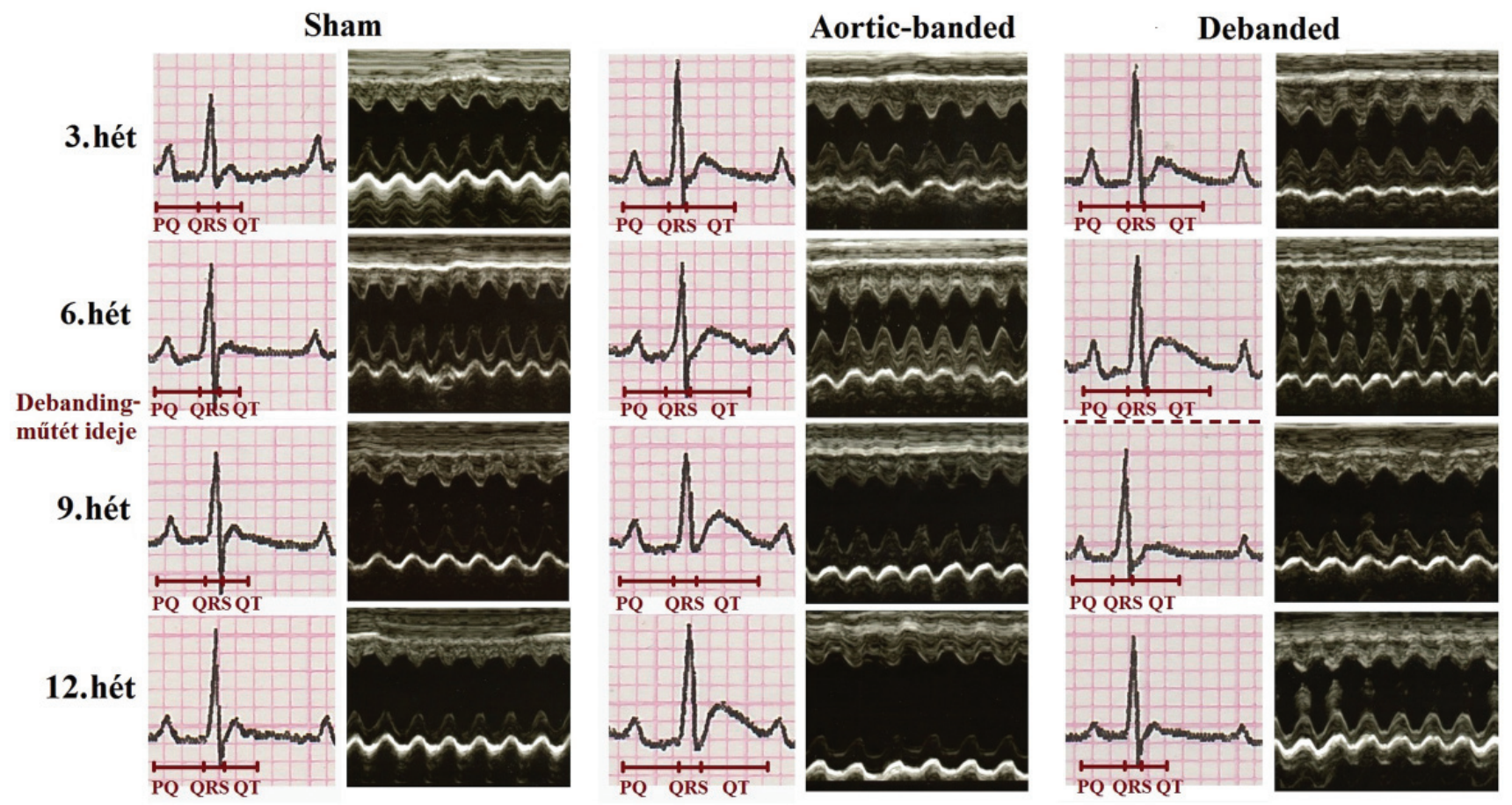

2. ÁBRA. A BKH kialakulásának és visszafejlődésének folyamatát szemléltető reprezentatív elektrokardiográfiás és echokardiográfiás felvételek. A BKH kialakulásának és visszafejlődésének morfológiai, funkcionális és elektromos eltéréseit szemléltető reprezentatív M-módú, a papilláris izmokat a középső síkban metsző szívultrahang és Il-es elvezetésű EKG-felvételek

továbbá megelőzte a szívfunkció fokozatos hanyatlását (2. táblázat és 3. D ábra).

\section{Az elektromos remodelláció és reverz remodelláció elektrokardiográfiás karakterizációja}

Az aortaszűkített állatoknál már a harmadik hét leteltével a QT-intervallum szignifikáns mértékủ megnyúlását tapasztaltuk, ami a kísérleti periódus végéig tovább fokozódott (2. és 3. A ábrák). A QT-intervallum megnyúlása erős korrelációt mutatott az LVmass (4. A ábra), a $C D(r=0,6332$; $\mathrm{p}=0,0001)$ és a HW/TL arány értékeivel $(r=0,8864$; $\mathrm{p}=0,0001)$. A PQ-intervallum megnyúlása a 9 . héttől vált megfigyelhetővé és mértéke szignifikáns összefüggést mutatott az EF (4. B ábra), a FS ( $r=-0,2874 ; p=0,0006)$, és az LW/TL arány értékeivel $(r=0,2889 ; p=0,0441)$. A QRS-komplexum kiszélesedését mind az AB-6hét és AB-12hét csoportnál tapasztaltuk (2. és 3. E ábra), ami jól korrelált a miokardiális fibrózis mértékével (4. C ábra), azonban a Cx43 expressziójával nem (Spearman $r=-0,04027 ; p=0,8327)$. A nyomásterhelés megszüntetése az említett paraméterek (QT, PQ, QRS) szempontjából jelentős védő hatást biztosított (2-3. ábrák).

\section{Az elektromos remodelláció és reverz remodelláció hátterében megfigyelhető fehérje expressziós változások} A western blot vizsgálat erős csökkenő tendenciát mutatott a Cx43 fehérje expressziójában mind az AB-6hét mind az AB-12hét csoportokban. A Debanded csoportban a $\mathrm{C} \times 43$ fehérje miokardiális szintje a kontrollcsoportok értékeihez tért vissza (5. A ábra). Az LTCC expressziója változatlan maradt minden kísérleti csoportban (5. B ábra). Ezzel szemben a hosszan fennálló nyomásterhelés következtében a 6 és 12 hetes aortaszűkített csoportokban tendenciálisan csökkent SERCA2-expresszió volt kimutatható, mely fehérje expreszsziója ugyanakkor a Debanded-csoportban a kontroll állatokra jellemző értékhez közelített (5. C ábra).

\section{Megbeszélés}

Jelen patkánykísérletünkben célunk volt a BKH kialakulásának és visszafejlődésének elektrokardiográfiával történő karakterizációja, valamint a reverz elektromos remodelláció hátterében meghúzódó elváltozások egyidejủ azonosítása. Tudomásunk szerint ez az első vizsgálat, amely e kórállapotban az EKG-n tapasztalható eltérések és a sejtszintü-, illetve funkcionális változások közötti kapcsolatot vizsgálja.

A nyomásterhelés megszüntetése a BKH visszafejlődésével párhuzamosan helyreállította a megnyúlt QT intervallumot A BKH-t kísérő leggyakoribb elektrofiziológiai eltérés az AP megnyúlása (4). Az AP időtartamának növekedése az EKG-n megnyúlt QT-intervallum formájában 
A

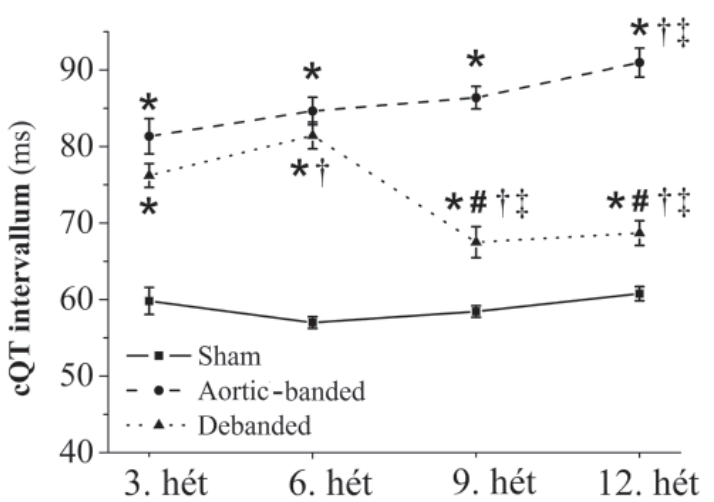

C

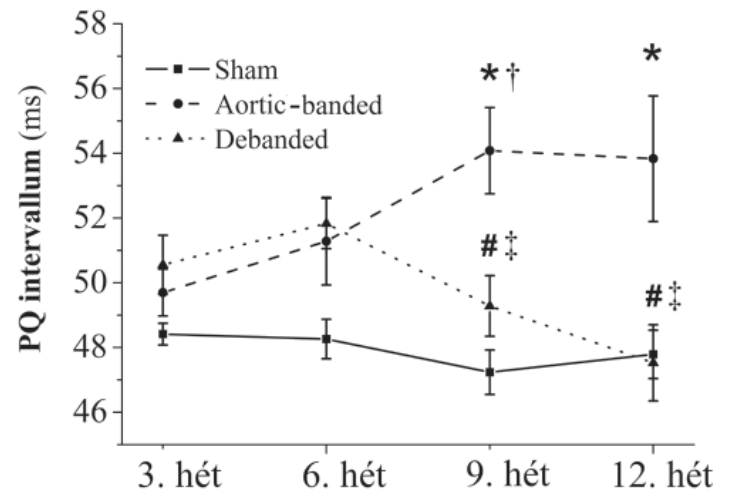

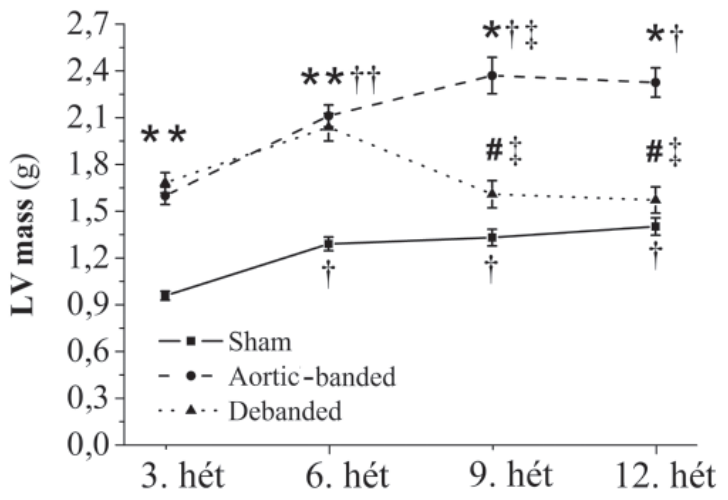

D

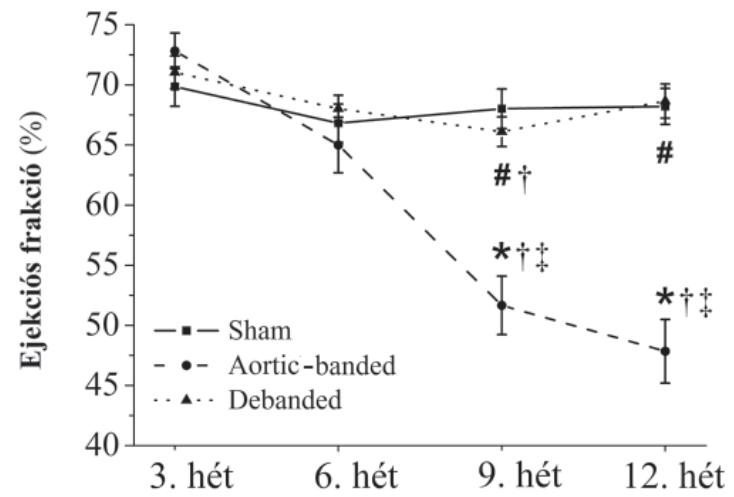

$\mathrm{E}$

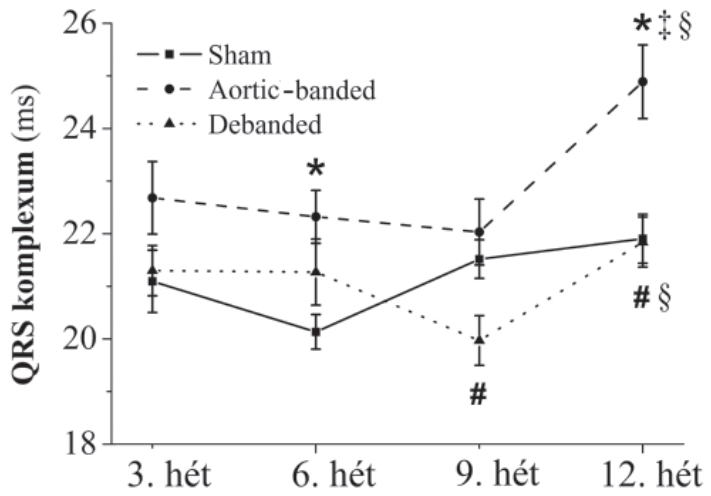

3. ÁBRA. A BKH kialakulásának és visszafejlődésének folyamatát szemléltető reprezentatív elektrokardiográfiás és echokardiográfiás felvételek. A BKH kialakulásának és visszafejlődésének morfológiai, funkcionális és elektromos eltéréseit szemléltető reprezentatív M-módú, a papilláris izmokat a középső síkban metsző szívultrahang és Il-es elvezetésű EKG-felvételek. A krónikus nyomásterhelés hatására a cQT és az LVmass értékei már a kísérleti időtartam 3. hetére szignifikáns mértékű növekedést mutattak. Ezen értékekben a 6., 9. és 12. hétre további növekedés volt megfigyelhető (A, B). Ezzel szemben a PQ megnyúlása és az EF csökkenése csak a 9. héten jelent meg (C, D). Végül a QRS kiszélesedése a 6. hét után vált egyértelművé (e). Az LVmass a bal kamrai tömeget jelöli. Minden értéket átlag \pm standard hiba formájában adtunk meg. * $p<0,05$ vs. Sham, ${ }^{\#}<0,05$ vs. $A B$, ${ }^{\dagger} p<0,05$ vs. 3 hetes, ${ }^{\ddagger} p<0,05$ vs. 6 hetes, ${ }^{\S} p<0,05$ vs. 9 hetes

manifesztálódik, amelynek megjelenése a korábbi kísérletes eredmények alapján szoros korrelációt mutat a BKH kialakulásával $(24,25)$. Kísérletünkben a fokozott nyomásterhelés hatására a mütétet követően már a 3. héten jelentős mértékü BKH volt kimutatható, amely együtt járt a cQT-intervallum megnyúlásával (2., 3., 4. A ábra). A kialakult szívizom-hipertrófia a 6. a 9. és a 12. hétre további progresszió mutatott, amelyet a szig- nifikánsan növekedett $L V$ mass, HW/TL és $C D$-értékei igazoltak (1. táblázat; 1. $A, B, 3$. B ábrák). A BKH súlyosbodása a QT-intervallum további hosszabbodását vonta maga után (2., 3.A ábra).

A BKH-ban megfigyelhető QT-intervallum megnyúlás hátterében a kifelé irányuló $\mathrm{K}^{+}$-áramok csökkenése és a befelé irányuló $\mathrm{Ca}^{2+}$-áram növekedése által előidézett meghosszabbodott repolarizációs idő állhat $(4,6)$. 
A

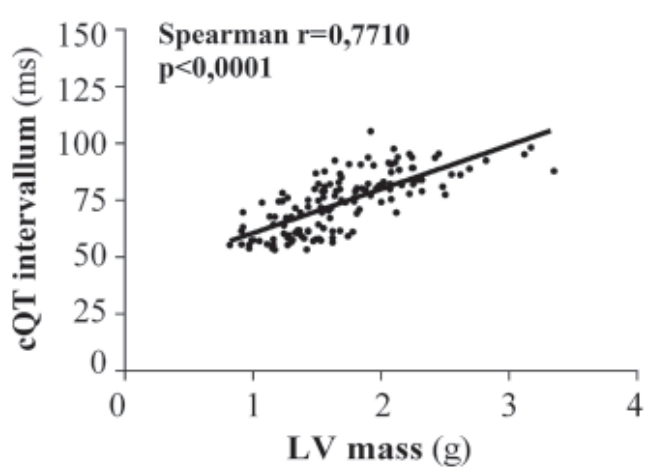

B

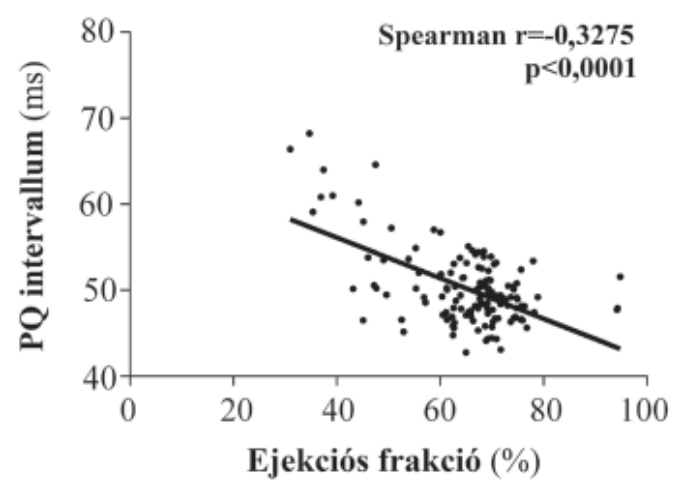

C

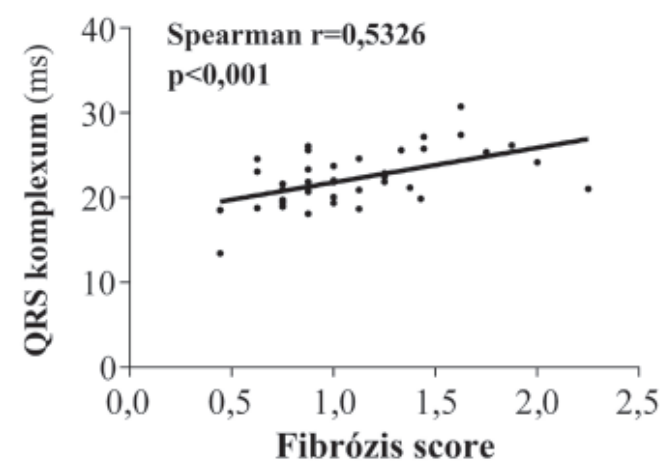

4. ÁBRA. Az EKG-eltérések és a morfológiai, illetve funkcionális változások között megfigyelt korrelációk a BKH kialakulása és visszafejlódése során.

A bal kamrai szívizomtömegben (LVmass) megfigyelt növekvő értékek erős korrelációt mutattak a cQT-intervallum megnyúlásával (A). Fordított összefüggést találtunk az EF és a PQ-intervallum értéki között (B). Végül a miokardiális fibrózis mértéke a QRS szélességével korrelált (C). Az LVmass a bal kamrai izomtömeget jelöli

A kórélettan az AP-hosszát a repolarizációs periódus hosszától teszi függővé, amely a két antagonista ionáram egymáshoz viszonyított állapota által meghatározott. A kifelé irányuló $\mathrm{K}^{+}$-áram ugyanis a szarkolemma gyors repolarizációjához vezet, amelyet a feszültségfüggő $\mathrm{Ca}^{2+}$-csatornák nyílása azonnal ellensúlyoz (26). Az így létrejövő egyensúlyi állapotoknak végül a $\mathrm{K}^{+}$-csatornák javára bekövetkező eltolódás vet véget, amely következtében a repolarizáció teljessé válik. Ezekből következik, hogy a két említett ionáram precíz szabályozása szükséges a fiziológiás QT-intervallum fenntartásához.

A Ca ${ }^{2+}$-csatornákban bekövetkező fehérje-expressziós változásokat illetően BKH és szívelégtelenség fennállása esetén megosztottak a tudományos vélemények. A nehézséget az okozza, hogy a BKH súlyossági fokától függően egyaránt jelentették az LTCC expressziójának növekedését (27), változatlanságát (27), illetve csökkenését (28) is. Humán szívelégtelen szívizom-mintákon végzett vizsgálatok megtartott $\mathrm{Ca}^{2+}$-áramot találtak a miokardiális LTCC kifejeződésének csökkenése ellenére, amit a csatorna fokozott foszforilációjával magyaráztak (28). Rágcsálókban a $\mathrm{Ca}^{2+}$-homeosztázisért felelős fehérjék megváltozott expresszióját azonosították a BKH-ban fennálló fokozott befelé irányuló $\mathrm{Ca}^{2+}$-áram fő okaként (4). Hipotézisük szerint a SERCA2 expreszsziójának csökkenése közvetett módon hozzájárul az LTCC fokozott aktivitásához BKH fennállása esetén. A SERCA2 csökkenése ugyanis csökkent $\mathrm{Ca}^{2+}$ indukálta $\mathrm{Ca}^{2+}$-felszabaduláshoz vezet a szarkoplazmás retikulumból, amely következtében a citoplazma lokális $\mathrm{Ca}^{2+}$-koncentráció alacsony marad és így az LTCC csatorna $\mathrm{Ca}^{2+}$-függő inaktivációja lassúbbá válik. Vizsgálatunkban az LTCC expressziója változatlan maradt a BKH kialakulásának ellenére (5. B ábra). Azonban a SERCA2 kifejeződése erős tendenciát mutatott a csökkenés irányába (5. $C$ ábra), ami tehát indirekt módon a mi modellünkben is hozzájárulhatott a QT-intervallum megnyúlásához.

Ugyanakkor a szükület eltávolítása a Debanded csoportban az LVmass, a HW/TL és a CD értékeket szignifikáns mértékben csökkentette, igazolva ezáltal a $B K H$ regresszióját (1. táblázat, 1. $A, B$ és 3 . $B$ ábrák). A hipertrófia visszafejlődéséhez a QT-intervallum rövidülése társult (2., 3. A ábrák), amelynek hátterében a SERCA2-fehérje expressziója által mutatott erős növekedő tendencia is állhat (5. C ábra).

A nyomásterhelés megszüntetése védett a szív funkcionális dekompenzációjával szemben és meggátolta a $P Q$-intervallum megnyúlását.

Vizsgálatunkban a QT-intervallummal ellentétben a $P Q$-intervallum megnyúlása nem követte a szívizom-hipertrófia növekedésének mértékét, ellenben korrelált a szívfunkció romlásával (4. B ábra). Eredményeinkkel összhangban, csökkent balkamra-funkcióval rendelkező, pangásos szívelégtelenségben szenvedő nyulakon végzett korábbi vizsgálatok az pitvar-kamrai junkció megnyúlásáról, bizonyos ioncsatornák expressziós szintủ változásairól és következményesen a PR-intervallum megnyúlásáról számolnak be (12).

Aortaszűkített állatainkban a pumpafunkció romlását a 9. hét elteltével az EF és a FS szignifikáns csökkenése jelezte (2. táblázat, 3. B ábra). Emellett a LVEDP és LW/ TL hányados értékeiben megfigyelt növekvő tendencia bizonyítékul szolgált a diasztolés diszfunkció és a viszszaható szívelégtelenség fennállására. A szívfunkció romlását jelző paraméterek (csökkent EF, FS és növe- 
A
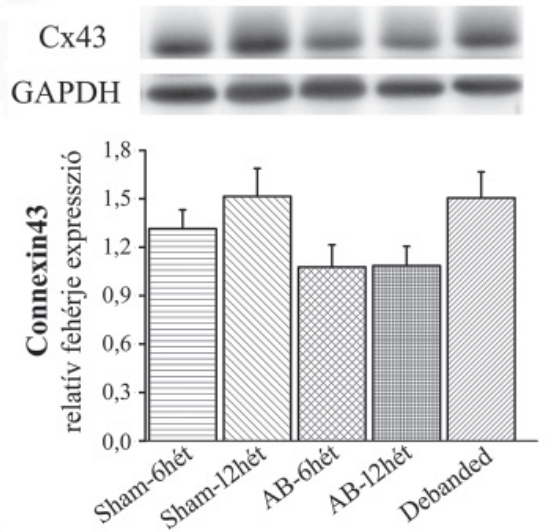

B
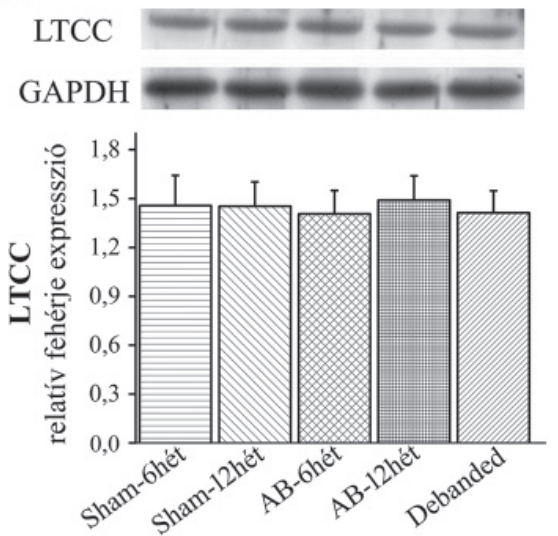

$\mathrm{C}$
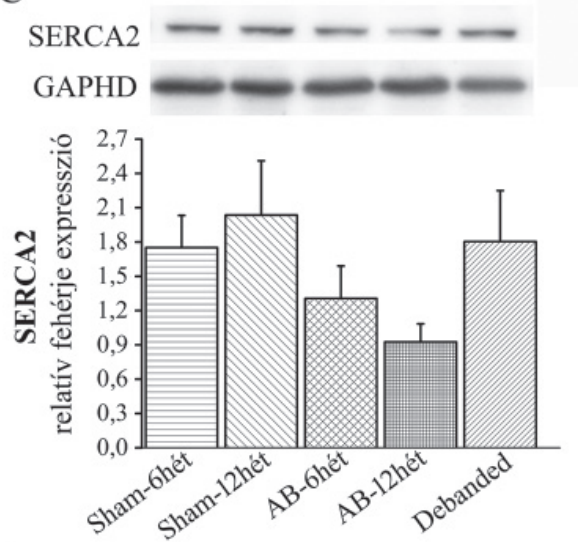

5. ÁBRA. A reverz elektromos remodelláció során megfigyelt fehérje-expressziós változások. A Cx43 immunblot analízise a 6 és 12 hetes aortaszúkített csoportban tendenciális csökkenést mutatott (A). Az LTCC expresszió mértéke az összes kísérleti csoportban változatlan maradt (B). Ugyanakkor a SERCA 2 fehérje szintjében a 6 és 12 hetes aortaszűkített csoportokban jelentős csökkenést tapasztaltunk, bár ezen változások mértéke sem érte el a statisztikai szignifikancia határát (C). A nyomásterhelés megszüntetése eredményesen előzte meg az említett fehérje-expressziós eltéréseket (A-C). $A C x 43$ a Connexin43-t, az LTCC az L-típusú Ca ${ }^{2+}$-csatorna fehérje $\alpha$ 1C-t, a SERCA2 a szarkoplazmás/endoplazmás retikulum Ca ${ }^{2+}$-ATPáz 2-t jelöli. Minden adatot átlagérték \pm SEM formájában adtunk meg. * $p<0,05$ vs. Sham, ${ }^{\#} p<0,05$ vs. AB-6hét, ${ }^{\$} p<0,05$ vs. AB-12hét.

kedett LW/TL hányados) szoros összefüggést mutattak a PQ-távolság megnyúlásával, amely szintén a 9. héttől vált megfigyelhetővé. Ebből kifolyólag feltételezhetjük, hogy kisállat-modellünkben a csökkent bal kamrai teljesítmény miatt másodlagosan megnövekedett bal pitvari nyomásterhelés hozzájárulhatott a $\mathrm{PQ}$-intervallum megnyúlásához.

Ugyanakkor a nyomásterhelés megszüntetése eredményesen előzte meg a BK funkcionális romlását és meggátolta a $\mathrm{PQ}$-intervallum meghosszabbodását (3. C, $D$ ábrák és 2. táblázat).

A nyomásterhelés megszüntetése megelőzte a QRS-komplexum kiszélesedését, csökkentette a miokardiális fibrózis mértékét és helyreállította a Cx43 expresszióját A széles QRS-komplexum a súlyosan szívelégtelen betegek gyakran diagnosztizált EKG eltérése (9), amely a halálozás pontos előrejelzőjének bizonyult (29). A QRS-komplexum kiszélesedésének hátterében a kamrák elektromos vezetőképességének lassulása áll. Az elektromos impulzus szívizomsejtek közti továbbítását fiziológiás körülmények fennállása esetén a következő két tényező biztosítja.

Az optimális ingerületvezetéshez egyrészt szükség van az egyes szívizomsejteket összekötő interkalált lemezeken található kis ellenállású intercelluláris ioncsatornák megfelelő denzitására, amelyek felépítésében a Cx43 fehérje kitüntetett szerepet játszik (30). Ebböl adódóan a Cx43 szerepe a szívelégtelenség talaján kialakuló aritmiákban intenzív kutatások tárgyát képezi. Expressziójának csökkenését számos különböző etiológiájú szívelégtelen beteg szívéből származó mintán kimutatták $(31,32)$. Ugyanakkor kompenzált BKH-ban megtartott vagy akár fokozott Cx43 fehérje-expressziót írtak le (31). Mindemellett aortaszúkített patkányokon végzett kísérletekben a Cx43 kóros, egyenlő sejtfelszíni eloszlását találták, ami az interkalált lemezeken csökkent koncentrációt eredményezett (33). A mi kísérletünkben a Cx43 szívizomszöveti expressziójának erősen csökkenő tendenciáját találtuk a 6 . és 12 . héten, bár ez nem érte el a szignifikancia küszöbét (5. $A$ ábra). Másrészt a szívizomsejtek közti kapcsolatot az intersticiális fibrózis mértéke is befolyásolja (3). Bár a kollagén struktúra adja a szív vázát, az extracelluláris mátrix túlzott felhalmozódása a sejtek közti kapcsolat zavarát idézheti elő, ami károsodott ingerületvezetést eredményezhet (10). Vizsgálatunkban a fokozott nyomásterhelés hatására csak a 12 . hét elteltével találtunk jelentősen fokozott miokardiális fibrózist.

Állatainkban a Cx43 expressziója nem, viszont a kollagén felhalmozódás mértéke szignifikáns korrelációt mutatott a QRS-komplexum kiszélesedésével. Ezek alapján feltételezhetjük, hogy kísérletünkben a miokardiális fibrózis növekedése járult hozzá leginkább a megfigyelt QRS-kiszélesedéshez.

Másrészről a nyomásterhelés megszüntetése megelőzte a myocardium fibrotikus elváltozásait (1. $A, C$ ábrák) és visszaállította a Cx43 expresszióját, ami együttesen védelmet biztosított a QRS-komplexum kiszélesedése ellen, és megtartotta a normális vezetést.

\section{Következtetések}

Vizsgálatunkban a fokozott nyomásterhelés kiváltotta BKH-t a QT- és PQ-intervallumok megnyúlása és a QRS-komplexum kiszélesedése jellemezték. Az EKG-eltérések a BKH kifejlődésének funkcionálisan különböző stádiumaiban jelentek meg, amelyek hátte- 
rében egyedi patomechanizmusokat azonosítottunk. A QT-intervallum megnyúlása jól korrelált a szívizom-hipertrófia kialakulásával, így már annak kompenzált stádiumában is jelen volt. A QT-intervallum megnyúlása mögött a SERCA2 szívizomszöveti kifejeződésének csökkenését azonosítottuk, mint fő molekuláris mechanizmust. A PQ-intervallum meghosszabbodása továbbá összefüggést mutatott a BKH funkcionális dekompenzációjával. Mindemellett kimutattuk, hogy a QRS kiszélesedéséért elsősorban a miokardiális fibrózis fokozódása, és nem a Cx43 expressziójának csökkenése tehető felelőssé.

A nyomásterhelés megszüntetése ugyanakkor maga után vonta a BKH szignifikáns regresszióját és a SERCA2 expressziójának helyreállását, amely folyamatok együtt jártak a QT-intervallum megrövidülésével. Továbbá a nyomásterhelés megszüntetése megőrizte a $B K$ funkcionalitását és ez által védett a $P Q$-intervallum megnyúlásával szemben is. Végül a csökkent miokardiális fibrózis és a fokozott Cx43 expresszió kivédte a QRS kiszélesedését is.

\section{Limitációk}

Vizsgálatainkat kizárólag fiatal hím patkányokon végeztük. Így további kutatások szükségesek a kor és a nem befolyásoló hatásának, illetve a fajok közti esetleges különbségek tisztázására.

Bár az elektrofiziológiai fundamentumok közösek a patkányok és emberek közt, bizonyos különbségek, úgymint a magasabb szívfrekvencia, rövidebb AP-időtartam, és a repolarizációért felelős $\mathrm{K}^{+}$-csatornák eltérő eloszlása, struktúrája és funkciója, említést érdemelnek.

Annak ellenére, hogy az $A B$ a nyomásterhelés okozta $\mathrm{BKH}$ elfogadott modellje, az abdomiális aorta mútét beszűkítése következtében a vesék hipoperfúziója alakulhat ki, ami a renin-angiotenzin-aldoszteron-rendszer aktiválódásával, így volumenretencióval járhat (34). Tehát nem zárható ki, hogy a modellünkben kifejlődött BKH-hoz volumenterhelés is hozzájárult.

Bemutatott kísérletes eredményeink direkt átültetése a klinikai gyakorlatba a fentebb ismertetett különbségek miatt nem lehetséges. Ugyanakkor vizsgálatunk olyan fontos összefüggésekre világít rá a reverz elektromos remodelláció során, mely megfigyelések alapjául szolgálhatnak további humán vizsgálatoknak.

\section{Köszönetnyilvánítás \\ Jelen munkánkat a Nemzeti Kutatási, Fejlesztési és Innovációs Hivatal - NKFIH (NVKP-16-1-2016-0017, „Nemzeti Szívprogram”); az Emberi Erőforrások Mi- nisztériuma ÚNKP-17-3-I-6-SE kódszámú Új Nemze- ti Kiválóság Programja (R.M.), a Magyar Tudományos Akadémia Bolyai János Kutatási Ösztöndíja (R.T.), a Baden-Württemberg tartomány és a Ruprecht-Karls Egyetem Orvostudományi kara (SK-I); támogatta. Elis- merés illeti Patricia Kraft, Tobias Mayer, Karin Sonnen- berg, Lutz Hoffmann és Gregor Viktória munkáját.}

\section{Irodalom}

1. Ruppert M, Korkmaz-Icoz S, Li S, Merkely B, Karck M, Radovits $\mathrm{T}$, et al. Reverse electrical remodeling following pressure unloading in a rat model of hypertension-induced left ventricular myocardial hypertrophy. Hypertens Res 2017; 40: 637-645. doi: 10.1038/hr.2017.1 2. McLenachan JM, Henderson E, Morris KI, Dargie HJ. Ventricular arrhythmias in patients with hypertensive left ventricular hypertrophy. N Engl J Med 1987; 317: 787-792. doi: 10.1056/ NEJM198709243171302

3. Wolk R. Arrhythmogenic mechanisms in left ventricular hypertrophy. Europace 2000; 2: 216-223. doi: 10.1053/eupc.2000.0110 4. Ahmmed GU, Dong PH, Song G, Ball NA, Xu Y, Walsh RA, et al. Changes in $\mathrm{ca}(2+)$ cycling proteins underlie cardiac action potential prolongation in a pressure-overloaded guinea pig model with cardiac hypertrophy and failure. Circ Res 2000; 86: 558-570. doi: 10.1161/01.RES.86.5.558

5. Teunissen BE, Jongsma HJ, Bierhuizen MF. Regulation of myocardial connexins during hypertrophic remodeling. Eur Heart J 2004; 25: 1979-1989. doi: 10.1016/j.ehj.2004.08.007

6. Tomita F, Bassett AL, Myerburg RJ, Kimura S. Diminished transient outward currents in rat hypertrophied ventricular myocytes. Circ Res 1994; 75: 296-303. doi: 10.1161/01.RES.75.2.296

7. Guo W, Li H, London B, Nerbonne JM. Functional consequences of elimination of $i(t o, f)$ and $i(t o, s)$ : Early after depolarizations, atrioventricular block, and ventricular arrhythmias in mice lacking kv1.4 and expressing a dominant-negative kv4 alpha subunit. Circ Res 2000; 87: 73-79. doi: 10.1161/01.RES.87.1.73

8. Hill JA. Hypertrophic reprogramming of the left ventricle: Translation to the ecg. J Electrocardiol 2012; 45: 624-629. doi: 10.1016/j. jelectrocard.2012.08.003

9. Kashani A, Barold SS. Significance of QRS complex duration in patients with heart failure. J Am Coll Cardiol 2005; 46: 2183-2192. doi: 10.1016/j.jacc.2005.01.071

10. Tanaka-Esposito C, Varahan S, Jeyaraj D, Lu Y, Stambler BS Eplerenone-mediated regression of electrical activation delays and myocardial fibrosis in heart failure. J Cardiovasc Electrophysiol 2014; 25: 537-544. doi: 10.1111/jce.12390

11. Wang Z, Kutschke W, Richardson KE, Karimi M, Hill JA. Electrical remodeling in pressure-overload cardiac hypertrophy: Role of calcineurin. Circulation 2001; 104: 1657-1663. doi: 10.1161/ hc3901.095766

12. Nikolaidou T, Cai XJ, Stephenson RS, Yanni J, Lowe T, Atkinson $\mathrm{AJ}$, et al. Congestive heart failure leads to prolongation of the pr interval and atrioventricular junction enlargement and ion channel remodelling in the rabbit. PLoS One 2015; 10: e0141452. doi: 10.1371/ journal.pone. 0141452

13. Gao XM, Kiriazis $H$, Moore XL, Feng XH, Sheppard K, Dart A, et al. Regression of pressure overload-induced left ventricular hypertrophy in mice. American journal of physiology. Heart and circulatory physiology 2005; 288: H2702-2707. doi: 10.1152/ajpheart.00836.2004

14. Ruppert M, Korkmaz-Icoz S, Li S, Nemeth BT, Hegedus P, Brlecic $P$, et al. Myocardial reverse remodeling after pressure unloading is associated with maintained cardiac mechano-energetics in a rat model of left ventricular hypertrophy. American journal of physiology. Heart and circulatory physiology 2016; 311: H592-603. doi: 10.1152/ajpheart.00085.2016

15. Rials SJ, Wu Y, Ford N, Pauletto FJ, Abramson SV, Rubin AM, et al. Effect of left ventricular hypertrophy and its regression on ventricular electrophysiology and vulnerability to inducible arrhythmia in the feline heart. Circulation 1995; 91: 426-430. doi: 10.1161/01. CIR.91.2.426

16. Olah A, Nemeth BT, Matyas C, Hidi L, Lux A, Ruppert M, et al. Physiological and pathological left ventricular hypertrophy of comparable degree is associated with characteristic differences 
of in vivo hemodynamics. American journal of physiology. Heart and circulatory physiology 2016; 310: H587-597. doi: 10.1152/ajpheart.00588.2015

17. Nemeth BT, Matyas C, Olah A, Lux A, Hidi L, Ruppert M, et al. Cinaciguat prevents the development of pathologic hypertrophy in a rat model of left ventricular pressure overload. Sci Rep 2016; 6: 37166. doi: $10.1038 / \mathrm{srep} 37166$

18. Kim HL, Kim YJ, Kim KH, Lee SP, Kim HK, Sohn DW, et al. Therapeutic effects of udenafil on pressure-overload cardiac hypertrophy. Hypertens Res 2015; 38: 597-604. doi: 10.1038/hr.2015.46

19. Korkmaz-Icoz S, Atmanli A, Radovits T, Li S, Hegedus P, Ruppert $\mathrm{M}$, et al. Administration of zinc complex of acetylsalicylic acid after the onset of myocardial injury protects the heart by upregulation of antioxidant enzymes. J Physiol Sci 2016; 66: 113-125. doi: 10.1007/s12576-015-0403-6

20. Devereux RB, Alonso DR, Lutas EM, Gottlieb GJ, Campo E, Sachs I, et al. Echocardiographic assessment of left ventricular hypertrophy: Comparison to necropsy findings. Am J Cardiol 1986; 57: 450-458. doi: 10.1016/0002-9149(86)90771-X

21. Pombo JF, Troy BL, Russell RO, Jr. Left ventricular volumes and ejection fraction by echocardiography. Circulation 1971; 43: 480-490. doi: 10.1161/01.CIR.43.4.480

22. Kmecova J, Klimas J. Heart rate correction of the QT duration in rats. Eur J Pharmacol 2010; 641: 187-192. doi: 10.1016/j.ejphar.2010.05.038

23. Korkmaz-Icoz S, Vater A, Li S, Lehner A, Radovits T, Hegedus $P$ et al. Mild type 2 diabetes mellitus improves remote endothelial dysfunction after acute myocardial infarction. J Diabetes Complications 2015; 29: 1253-1260. doi: 10.1016/j.jdiacomp.2015.06.012

24. Boulaksil M, Noorman M, Engelen MA, van Veen TA, Vos MA, de Bakker JM, et al. Longitudinal arrhythmogenic remodeling in a mouse model of longstanding pressure overload. Neth Heart J 2010; 18: $509-515$

25. Klimas J, Kruzliak P, Rabkin SW. Modulation of the qt interva duration in hypertension with antihypertensive treatment. Hypertens Res 2015; 38: 447-454. doi: 10.1038/hr.2015.30

26. Farraj AK, Hazari MS, Cascio WE. The utility of the small rodent electrocardiogram in toxicology. Toxicol Sci 2011; 121: 11-30. doi: 10.1093/toxsci/kfr021

27. Schroder F, Handrock R, Beuckelmann DJ, Hirt S, Hullin R, Priebe $L$, et al. Increased availability and open probability of single I-type calcium channels from failing compared with nonfailing human ventricle. Circulation 1998; 98: 969-976. doi: 10.1161/01.CIR.98.10.969 28. Chen X, Piacentino V, 3rd, Furukawa S, Goldman B, Margulies KB, Houser SR. L-type ca2+ channel density and regulation are altered in failing human ventricular myocytes and recover after support with mechanical assist devices. Circ Res 2002; 91: 517-524. doi: 10.1161/01.RES.0000033988.13062.7C

29. Iuliano S, Fisher SG, Karasik PE, Fletcher RD, Singh SN, Department of Veterans Affairs Survival Trial of Antiarrhythmic Therapy in Congestive Heart F. Qrs duration and mortality in patients with congestive heart failure. Am Heart J 2002; 143: 1085-1091. doi: 10.1067/mhj.2002.122516

30. Sohl G, Willecke K. Gap junctions and the connexin protein family. Cardiovasc Res 2004; 62: 228-232. doi: 10.1016/j.cardiores.2003.11.013

31. Kostin S, Dammer S, Hein S, Klovekorn WP, Bauer EP, Schaper J. Connexin 43 expression and distribution in compensated and decompensated cardiac hypertrophy in patients with aortic stenosis. Cardiovasc Res 2004; 62: 426-436. doi: 10.1016/j.cardiores.2003.12.010

32. Kostin S, Rieger M, Dammer S, Hein S, Richter M, Klovekorn WP, et al. Gap junction remodeling and altered connexin43 expression in the failing human heart. Mol Cell Biochem 2003; 242: 135-144. doi: 10.1023/A:1021154115673

33. Emdad L, Uzzaman M, Takagishi Y, Honjo H, Uchida T, Severs $\mathrm{NJ}$, et al. Gap junction remodeling in hypertrophied left ventricles of aortic-banded rats: Prevention by angiotensin ii type 1 receptor blockade. J Mol Cell Cardiol 2001; 33: 219-231. doi: 10.1006/ jmcc. 2000.129

34. Massart PE, Donckier J, Kyselovic J, Godfraind T, Heyndrickx GR, Wibo M. Carvedilol and lacidipine prevent cardiac hypertrophy and endothelin-1 gene overexpression after aortic banding. Hypertension 1999; 34: 1197-1201. doi: 10.1161/01.HYP.34.6.1197

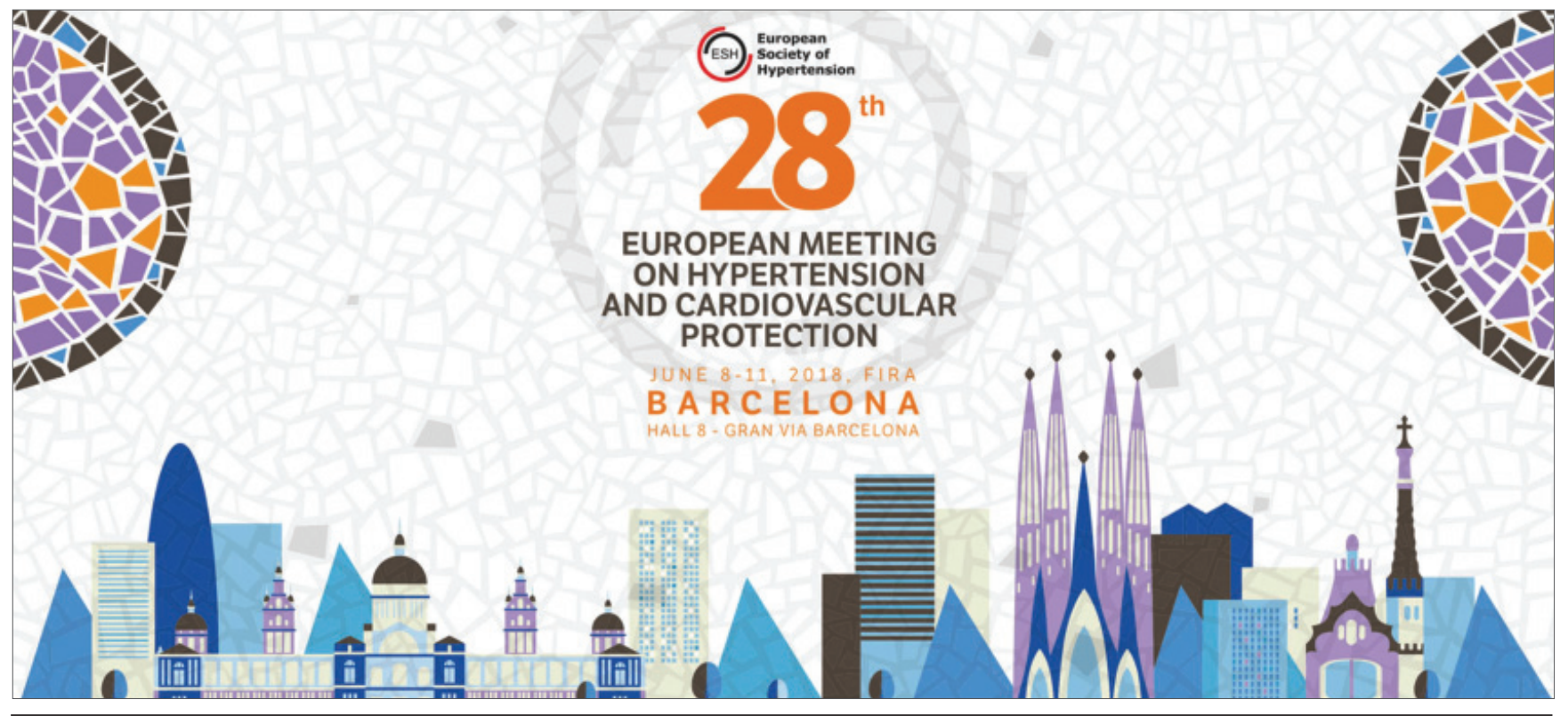

